\title{
DNA Reactive Activities of Some Endogenous Metabolites and their Putative Role in the Induction of Cancer
}

\section{Nida Rehmani and SM Hadi*}

Department of Biochemistry, Faculty of Life Sciences, Aligarh Muslim University, Aligarh, Uttar Pradesh, India

\begin{abstract}
One of the most intriguing scientific mysteries is the origin of cancer. DNA damage plays a potent role in mutagenesis, carcinogenesis and ageing. There has been growing realization in recent years that endogenous substrates or metabolites may be an important source of damage caused to cellular DNA. Further, evidence indicates that endogenous DNA damage occurs at a high frequency as compared to exogenous damage. Such findings have debunked the notion that the genetic material is pristine in the absence of exogenous carcinogens. An in-depth knowledge of the types of endogenous DNA damage is essential for understanding the influence of damage caused by endogenous substrates on the induction of cancer. Therefore, in this review, we have focused on several classes of endogenous metabolites and their putative role in mutagenesis and carcinogenesis from a structural, biological and analytical perspective. The mechanisms by which endogenous substrates may contribute to cancer pathogenesis have also been discussed with the objective that the implications from the findings summarised may pave way for a better understanding of the mechanisms underlying the induction of disease such as cancer. These results, complemented by other data, strongly support one of the theories of carcinogenesis according to which endogenous agents may have a major contribution in spontaneously induced cancer. It is obvious that if an approach could be developed leading to a diminution in endogenous DNA damage, the incidence of diseases such as cancer might be significantly reduced.
\end{abstract}

Keywords: DNA; Damage; Endogenous; Metabolites; Carcinogenesis; Mutagenesis

\section{Introduction}

Cancer is a disease that initiates with mutation of essential regulatory genes such as, oncogenes and tumor suppressor genes [1]. Successive accumulation of mutations in genes is considered to be basic to the process of carcinogenesis [2] (Figure 1). As to how the cancer causing mutations arise has been the question at the heart of the field ever since.

In the late 1960s, James and Elizabeth Miller proposed a hypothesis stating the basic principles of carcinogenesis $[3,4]$. They proposed that the first step in the multi stage phenomenon of tumorigenesis is the covalent binding of chemicals to cellular macromolecules, DNA, RNA and proteins. These chemicals or species are able to react with macromolecules owing to their electrophilicity. Since the publication of this hypothesis, researchers have been highly interested in elucidating the mechanisms underlying chemical carcinogenesis. Studies in this discipline have shown that carcinogenesis by several chemicals involves either a direct action of the chemical on cellular DNA or conversion of the parent chemical to a reactive form, which can then react with cellular DNA to produce permanent changes in the DNA [5].

DNA damage is known to play a potent role in mutagenesis and carcinogenesis [6] (Figure 1). Reaction of DNA bases with electrophilic agents, oxidising substrates, reactive metabolites or ultraviolet light produces covalently modified bases that are termed as DNA adducts [7-10]. Most of the research has focused on adducts derived from chemicals of exogenous origin such as hydrocarbons, aromatic amines, mycotoxins, etc. However, even in DNA of normal cells, several categories of endogenous adducts have been detected. Such adducts include oxidized bases, alkylated bases, exocyclic base adducts, and a range of unidentified adducts referred to as I-compounds [11]. Identification of these adducts by various techniques has led to an understanding of why and how they can initiate cancer $[12,13]$.
The etiology of most human cancers remains unknown but it is presumed that the major carcinogenic risk to humans is posed by endogenous carcinogens. DNA mutation is an essential step in carcinogenesis and increased levels of DNA lesions have been detected in various tumors, implying the role of such damage in the etiology of cancer [14]. It is known that oxidatively modified DNA is abundant in many human tissues, especially in tumors $[15,16]$.

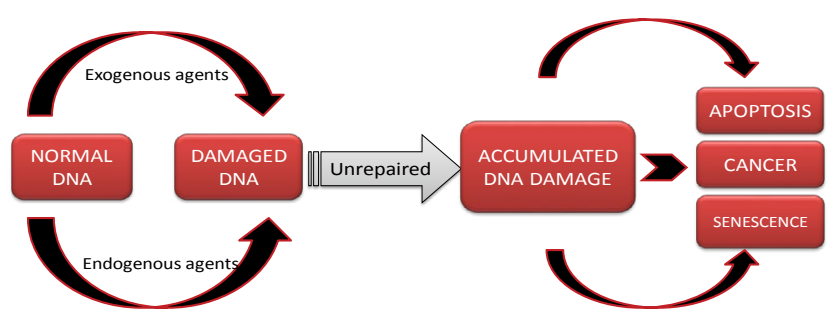

Figure 1: Schematic representation of DNA damage and its consequences: The genetic material i.e. DNA sustains damage from both exogenous and endogenous sources. If the successive accumulation of DNA damage goes unrepaired, it can lead to apoptosis, senescence or cancer.

*Corresponding author: SM Hadi, Department of Biochemistry, Faculty of Life Sciences, Aligarh Muslim University, Aligarh, Uttar Pradesh, India, Tel: +91-5712700741/400741; Fax: +91-571-400466; E-mail: smhadi@vsnl.com

Received June 30, 2015; Accepted August 21, 2015; Published August 25, 2015

Citation: Rehmani N, Hadi SM (2015) DNA Reactive Activities of Some Endogenous Metabolites and their Putative Role in the Induction of Cancer. J Cancer Sci Ther 7: 283-291. doi:10.4172/1948-5956.1000364

Copyright: @ 2015 Rehmani N, et al. This is an open-access article distributed under the terms of the Creative Commons Attribution License, which permits unrestricted use, distribution, and reproduction in any medium, provided the original author and source are credited. 
Historically, research into the role of DNA damaging agents has focused primarily on toxic chemicals of exogenous origin, attention is now being shifted to by-products of endogenous origin [17]. Evidence indicates that endogenous DNA damage occurs at a high frequency as compared to exogenous damage and the types of damage caused as a result of endogenous cellular processes are identical or similar to those produced by various exogenous agents [18]. This emphasis on the role of endogenous metabolites as DNA damaging agents is due to the technological developments that are able to detect adducts of endogenous origin in cellular DNA [19-23]. While studying the role of exogenous carcinogens in animal models, analogous DNA adducts were also found in control groups [24]. Research studies like this triggered the search for the physiological substrates that produced these DNA adducts and other pathways that lead to endogenous genotoxicity.

There is increasing evidence that considerable DNA damage is caused by adducts produced from endogenous substrates that arise as a result of normal or aberrant metabolism. For example, malondialdehyde which is produced as a result of lipid peroxidation and eicosanoid metabolism has been shown to react with cellular DNA to form a propanodeoxy-guanosine adduct $[25,26]$. Further, there has been evidence that this adduct exists at significant levels in the DNA of rats and humans and is also an efficient mutagen in E.coli $[25,26]$. Thus, there is strong implication that adducts formed by endogenous substrates may contribute to the etiology of genetic diseases and therein the baseline of human cancer.

Based on the multitude of evidences on the role of endogenous metabolites as DNA damaging agents, studies in our laboratory have also shown that several classes of endogenous metabolites such as L-DOPA [27], Uric acid [28], Serotonin [29], Melanin [30], and Bilirubin [31], etc. are capable of causing DNA breakage. We have also proposed a probable mechanism for the genotoxicity induced by these endogenous substrates (Figure 2). Our studies suggest that these metabolites are capable of binding to DNA as well as $\mathrm{Cu}$ (II). A ternary complex of DNA-Cu (II)-endogenous metabolite may thus be formed owing to such binding affinities. These metabolites have also been shown to generate harmful reactive oxygen species either alone or in the presence of transition metal ions such as $\mathrm{Cu}$ (II) which ultimately cause cellular DNA breakage. We have earlier proposed that several antioxidants, both of plant and animal origin such as uric acid [28], tannic acid [32,33] and flavonoids [34] are capable of acting as pro- oxidants under appropriate conditions or microenvironment. Our studies provide strengthening evidence for the role of the endogenous chemicals as genotoxins in spontaneously induced cancer.

In this review, we have discussed several classes of endogenous metabolites in relation to their putative DNA damaging potentials. The findings will hopefully help frame questions about the risks posed by endogenous metabolites and encourage further research to answer some of these questions. Further, it is hoped that this study will provide insight into the contribution of endogenous DNA damage which leads to mutagenesis, wherein lies the baseline of human cancer.

\section{Pro-oxidant and antioxidant properties of uric acid}

Uric acid (2, 6, 8-trioxopurine) (Figure 3 ) is formed in mammals as an end product of purine metabolism [28]. It is derived exclusively from the oxidation of xanthine and hypoxanthine by the enzyme Xanthine Oxido Reductase [35]. In the human plasma, uric acid is present in saturating concentrations (up to $0.6 \mathrm{mM}$ ) [36], making it one of the major antioxidants in humans. Numerous studies have shown that uric acid is able to scavenge singlet oxygen $[37,38]$ as well as hydroxyl radicals [39].

\section{Antioxidant potential of uric acid}

Over the past 60 million years, a marked increase in life-span has occurred in human evolution [40]. It seems evident that the evolution of protective mechanisms against oxygen radicals may have been a major factor in increasing the life span of humans and decreasing the rates of age related cancers [40-46]. In 1982, Ames et al proposed that uric acid provides a primary defence against human cancer and it may be partly responsible for relatively long life span of humans based upon its high serum concentration, its capacity to scavenge singlet oxygen and to inhibit lipid peroxidation in humans [47]. Since the publication of this hypothesis, numerous reports documenting the role of uric acid as an antioxidant were generated in the ensuing years [48].

\section{Uric acid and disease risk}

There has been increasing concern that hyperuricemia may have a significant role in various disorders such as hypertension [49], acute renal injury [50], cardiovascular disease [51-53] and MetS-metabolic syndrome [54-56]. Owing to its low solubility, elevated uric acid in blood gets deposited in tissues leading to some disease conditions like

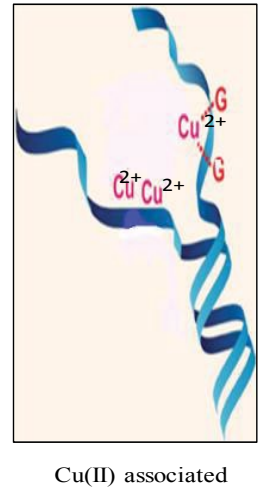

with DNA

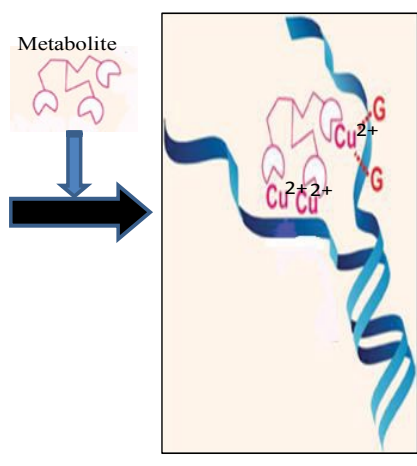

DNA- Cu(II)- metabolite complex

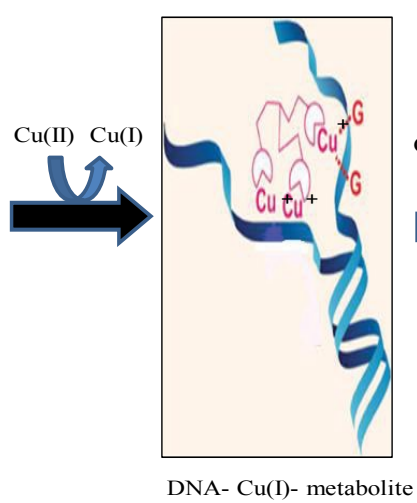

complex

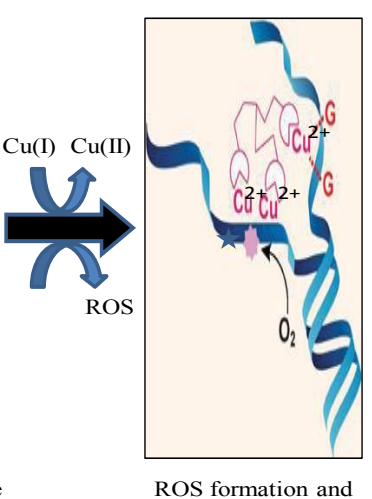

Figure 2: The schematic model proposed for the formation of a ternary complex: the redox cycling of endogenous metabolite, DNA and copper ion complex leads to generation of reactive oxygen species (ROS) which inflicts breakage in DNA. 
<smiles>O=c1[nH]c(=O)c2[nH]c(=O)[nH]c2[nH]1</smiles>

Figure 3: The chemical structure of uric acid (2, 6, 8- trioxopurine).

gout or rheumatoid arthritis [28]. Although uric acid is known as a potent antioxidant, recent studies have demonstrated that elevated serum uric acid is independently and significantly associated with excess cancer risk and mortality [57]. There is a relevant correlation of hyperuricemia with augmented risk of certain cancers like colorectal, breast and prostate and others [58-62]. It has been suggested that its pro-inflammatory properties may have an important contribution in the pathogenesis of cancer [57]. Furthermore, statistical data suggests that elevated serum uric acid is strongly associated with increased premature cancer death in both men and women [63-65]. In a study involving patients with terminally end stage cancer, high levels of serum acid were predictive of reduced survival time of the patients [66]. Evidence indicates that there is a dose dependence and time varying link of serum uric acid with cancer mortality [67]. Based on extensive data, it has been proposed that excess uric acid (intracellular and extracellular) contributes to tumorigenesis. According to this model, elevated serum uric acid when present extracellularly, stimulates tumor cell proliferation and migration and it induces inflammatory stress causing transformation, when it enters the cell [57]. Such studies are implicative of a more intricate role of uric acid in cancer biology than that of a general antioxidant.

\section{Pro-oxidant effects of uric acid}

It is known that uric acid is able to bind $\mathrm{Cu}$ (II) [68]. Our studies on uric acid have demonstrated that it can cause breakage of calf thymus DNA and supercoiled plasmid DNA in the presence of $\mathrm{Cu}$ (II) and molecular oxygen. We have shown that uric acid generates hydroxyl radicals in the presence of $\mathrm{Cu}$ (II) and it also causes the reduction of $\mathrm{Cu}$ (II) to $\mathrm{Cu}$ (I) which is an essential intermediate in the DNA cleavage reaction. The involvement of oxygen species in the reaction was confirmed by the inhibition of DNA breakage in the presence of oxygen radical scavengers [28].

Based on the abovementioned studies, we have proposed the formation of a ternary complex by the uric acid, DNA and Cu (II) system which could damage DNA. There is also a possibility of formation of urate anion by the reaction of uric acid with oxygen radicals. The urate anion has been shown to inactivate enzyme systems and thus may be able to damage DNA [69]. Our results do not detract from the established antioxidant role of uric acid in extracellular fluids. Instead, our studies support the idea that several antioxidants (in this case, uric acid), are able to act as pro-oxidants under appropriate conditions.

\section{DNA reactive activities of bilirubin and its metabolic precursor biliverdin}

Biliverdin (Figure 4A) and bilirubin (Figure 4B) are heme degradation products. Heme is degraded to biliverdin by the action of heme oxygenase. Biliverdin is further reduced to bilirubin mediated by biliverdin reductase [70]. These bile pigments have been attributed with harmful as well as beneficial properties. Both bilirubin and biliverdin have been reported to play antioxidant roles in the body based on their radical scavenging properties [71]. For example, it has been shown that these compounds can prevent superoxide production [72], quench singlet oxygen [73], inhibit lipid peroxidation [74] and scavenge peroxynitrite $[75,76]$.

Biliverdin is considered as a soluble and non-toxic compound [77]. Although, some studies have indicated that it can have toxic roles. It has been found that biliverdin concentrations are significantly increased in hepatic necrosis [78]. Evidence indicates that biliverdin can also cause overexpression of some oncogenes in the liver [79]. It has also been associated with Bronze Baby syndrome [80].

Normal plasma concentrations of bilirubin range from 5 to $17 \mu \mathrm{M}$ [81] almost all of which is bound to albumin [82] or exists as a conjugate with glucuronic acid [83]. Albumin bound bilirubin is considered one of the naturally occurring antioxidants of human extracellular fluids [68]. It was the pioneering study by [84] which launched the idea that endogenous bilirubin is one of the most potent antioxidants in the serum. Further studies have demonstrated that bilirubin reduces oxidative stress in neurons [85] and cardiomyocytes [86].

It has also been found that bilirubin functions as a physiological neuroprotectant [85]. As reported by Hayashi et al., bilirubin also exerts anti-inflammatory effects [87]. Contrary to these findings, several studies have shown that bilirubin is toxic to cells in vitro as well as in vivo $[88,89]$. Increased levels of bilirubin in plasma are known to be related with disease conditions such as jaundice and hyperbilirubinemia [83]. Further, it has also been found that elevated concentrations of bilirubin (greater than $300 \mathrm{uM}$ ) may contribute to the development of neurological dysfunctions [90] as well as impairment of cellular functions in brain [91]. Inhibition of various membrane bound enzymes by bilirubin has also been reported [92].

\section{Evidence for pro-oxidant activity}

In vitro studies in our laboratory have aimed at elucidating the

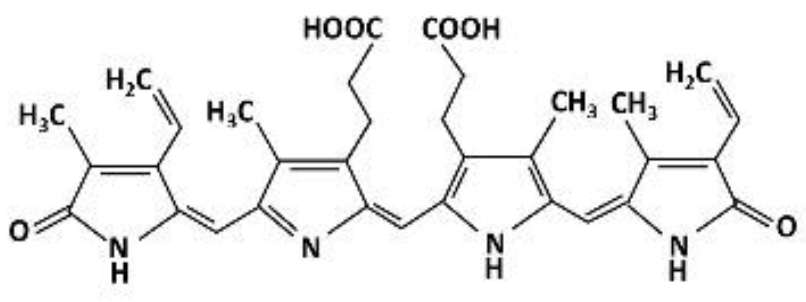

A. Biliverdin

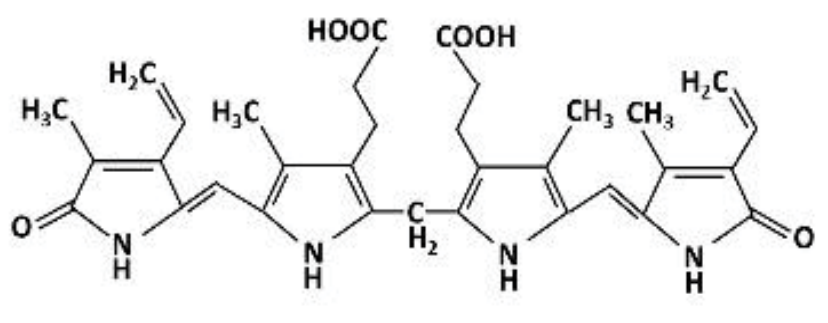

B. Bilirubin

Figure 4: The chemical structures of $A$ ) biliverdin and its metabolic derivative B) bilirubin. 
mechanism of DNA breakage reaction by these bile pigments. Our results have indicated that bilirubin is able to cause strand scission in DNA in the presence of $\mathrm{Cu}(\mathrm{II})$ via generation of reactive oxygen species [31]. Subsequently we compared the antioxidant and prooxidant activities of biliverdin and its metabolic derivative bilirubin [71]. Our findings imply that bilirubin, as compared to its metabolic precursor biliverdin is more efficient as an antioxidant and also as a prooxidant. Although there is enough evidence in the literature implicative of the toxic effects of these metabolites, the present literature is not sufficient to explain whether the elevated levels of these bile pigments are the result or cause of the toxicity.

\section{Role of estrogens and their metabolites as genotoxic agents}

Naturally occurring estrogens (Estrone E1, Estradiol E2, Estriol E3) are a group of steroidal compounds (Figure 5). Although the physiological action of estrogens occurs at hormone responsive organs (testis, uterus, pituitary), they also exert some action at other organs (kidney, liver etc.) as well [93]. Numerous in vitro and in vivo studies have demonstrated that estrogens possess antioxidant properties [94]. It has been established that all estrogens at their micromolar concentrations exert antioxidant action [95-97].

Earlier research categorised estrogens as non genotoxic due to the inability of these metabolites to induce gene mutations in classical bacterial and mammalian mutation assays [98-100]. Nevertheless, with the advancements in sensitive methods to detect adducts and a thorough understanding of the estrogen metabolism, there has been strengthening evidence in support of estrogen mediated genotoxicity [101-103]. Pharmacological levels of estrogens have been shown to produce adverse effects such as embryotoxicity, teratogenicity and carcinogenicity $[104,105]$. Studies on animal models have documented that estrogens can act as tumor initiators $[106,107]$. Further, elevated concentrations of estrogens have also been found to be associated with cancer in humans.<smiles>O=C1CCC2C1CCC1c3ccc(O)cc3CCC12</smiles><smiles>Oc1ccc2c(c1)CCC1C2CCC2(O)CCCC12</smiles><smiles>CC12CCC3c4ccc(O)cc4CCC3C1CC(O)C2O</smiles>

C. Estriol

Figure 5: Chemical structures of natural estrogens: A) Estrone [E1]; B) Estradiol$17 \beta[E 2]$ and C) Estriol [E3].
In 1960s and 1970s, the initial evidence for the DNA binding activity of estrogen metabolites was obtained [93]. In the ensuing years, more studies started shedding light on the diverse types of genetic insults caused by estrogens and their metabolites. It has been reported that the estrogens, estrone and estradiol are able to react with DNA as well as proteins $[108,109]$. Although the estrogen hormones are not able to link covalently with DNA per se, but their reactive metabolites are known to form covalent bonds with nucleotide bases [93]. Catecholestrogens, the major metabolites of the estrogens are known to oxidise to yield quinones which may form adducts by reacting with DNA. A hypothesis holds that these adducts may generate mutations that might initiate many human cancers [110]. Stack et al. [111] and Cavalieri et al. [112] have shown that various metabolites of estrogens, specifically estrone 3, 4-quinone are able to form unstable adducts by reacting with DNA bases. In an in vivo study involving hamsters, it was found that exposure to estrogens for several months resulted in the enhancement of DNA adducts in kidney of the hamsters [113-115]. In another experiment, co-administration of estrogen with an anti-estrogen failed to affect the increase in adduct levels caused by estrogens [116].

Active oxygen radicals are known to be produced by the redox cycling of catecholestrogen metabolites [93]. Microsomal enzymes such as P450 are capable of catalysing the redox cycling of estrogen metabolites and thus generate oxygen radicals [117-119]. In a recent study, Seacat et al. [120] have shown that metal ions such as $\mathrm{Cu}$ (II) can also catalyse the oxidation of catecholestrogens generating hydroxyl radicals. The free radicals produced by redox cycling of estrogens enzymatically or non-enzymatically can induce DNA damage by different mechanisms [93]. For example, Nutter et al [121,122] have shown that the free radicals produced by the oxidation of estrogen quinones in cells are capable of inducing single strand breaks in DNA. Further, the reactive species produced by catecholestrogens have also been implicated in causing structural aberrations in the chromosomes [93].

Although, the parent estrogen hormones do not possess reducing properties, estrogen metabolites such as catecholestrogens are capable of reducing metal ions such as $\mathrm{Cu}^{2+}$ to $\mathrm{Cu}^{+}$or $\mathrm{Fe}^{3+}$ to $\mathrm{Fe}^{2+}$ [94]. The reducing capability of catecholestrogens may be attributed to their catechol structure which is absent in the parent hormones. It can be presumed that the mechanism of the pro-oxidant effect of catecholestrogens is based upon their capability of reducing transition metal ions such as $\mathrm{Cu}$ (II) to $\mathrm{Cu}$ (I) ions which has been shown to initiate lipid peroxidation via generation of free radicals [123]. Evidence has also indicated the pro-oxidant effect of estrogens metabolites in vivo [124-126].

Altogether, these studies emphasize the genotoxic effects of estrogen which have received little attention in the past. These findings are implicative of the possible role of estrogens in the complex process of hormone-induced carcinogenesis.

\section{Contribution of neurotransmitters in carcinogenesis}

Serotonin (5-hydroxytryptamine) is biochemically derived from the amino acid, tryptophan (Figure 6A). It is an important neurotransmitter in brain and spinal cord and affects several behaviours such as hunger, aggressiveness, sleep, mood and consciousness [127]. Studies in our laboratory have demonstrated that serotonin can cause strand breakage in DNA in the presence of $\mathrm{Cu}$ (II) via an oxidative mechanism [29]. We have shown that serotonin catalyses the reduction of $\mathrm{Cu}$ (II) to $\mathrm{Cu}$ (I) and this reaction is accompanied with hydroxyl radical formation. In order to elucidate the chemical basis of the DNA 
breakage by serotonin, we also compared the efficiency of DNA cleavage of serotonin with its structurally related metabolites i.e. tryptophan and melatonin [127]. It has been reported that copper ions can bind to serotonin as well as its metabolite melatonin [128] (Figure 6B). Our studies indicated that only serotonin-Cu (II) complex is efficient in degrading DNA as compared to melatonin-Cu (II) or tryptophan-Cu (II). Based on our results, we have proposed that the phenolic group present in serotonin is important in causing DNA strand cleavage in the presence of $\mathrm{Cu}(\mathrm{II})$ and that this interaction involves the formation of quinone methide [127].

L-DOPA (L-3,4 dihydroxyphenylalanine) (Figure 6C) is formed from the hydroxylation of the amino acid, L-tyrosine mediated by the enzyme tyrosine hydroxylase. It serves as a metabolic precursor in several metabolic reactions such as the synthesis of melanin, dopamine, adrenaline and nonadrenaline. The nervous system is extensively rich in L-DOPA and its metabolites (dopamine, 3-o-methyl dopa) [129]. L-DOPA is prescribed as a drug to Parkinson's patients for replenishing the loss of dopamine in human brain. In 1994, Halliwell and co-workers had proposed that L-DOPA and its metabolites can cause extensive DNA damage in the nervous system. In the ensuing years, numerous in vitro and in vivo studies were reported documenting the toxicity of L-DOPA and its metabolites.

Dopamine (Figure 6D) is formed from L-DOPA by the action of dopa decarboxylase. It is a chemical neurotransmitter in the central nervous system and accounts for $90 \%$ of the total catecholamines [27]. The dopaminergic system is involved in regulating various physiological processes such as emotion, cognition, neuromodulation, etc. [130-132]. Evidence has indicated that dopamine is capable of interacting with DNA [133]. It has been proposed that the availability<smiles>N[C@@H](Cc1ccc(O)c(O)c1)C(=O)O</smiles><smiles>NCCc1ccc(O)c(O)c1</smiles>

A I_nND A<smiles>NCCc1c[nH]c2ccc(O)cc12</smiles>
B. Dopamine<smiles>CC1NCCc2cc(O)c(O)cc21</smiles>
C. Serotonin D. Salsolinol<smiles>COc1ccc2[nH]cc(CCNC(C)=O)c2c1</smiles>

E. Melatonin

Figure 6: The structures of some neurotransmitters and related metabolites $A$ ) L-DOPA B) dopamine C) serotonin D) salsolinol and E) melatonin. of redox active catecholamines such as dopamine in the presence of copper ions may lead to cytotoxicity in the brain [129]. Further, the oxidative metabolism of dopamine and other catecholamines has been implicated in the generation of free radicals and quinines [134-136]. Numerous studies have documented the toxicity of dopamine and its metabolites in relevance to Parkinson's disease [137-140]. Thus, it is a matter of concern that the current drug for Parkinson's disease i.e. L-DOPA may increase the risk of such oxidative damage [141]. It has also been reported that dopamine can induce apoptosis in cells and thus it is implicated to possess antitumor properties [142,143].

Dopamine combines with acetaldehyde, to yield 1-methyl-6,7diydroxy-1,2,3,4 tetra hydroisoquinoline (Salsolinol) [144,145] (Figure $6 \mathrm{E})$. This metabolite has been identified in rats and human brain tissues $[146,147]$. It has been speculated that salsolinol plays an important role as a neuromodulator of catecholaminergic neurotransmission [148]. It has been found that the neuromodulator function of salsolinol bears resemblance to L-DOPA remarkably [149-151]. Although, convincing evidence indicates that salsolinol and its metabolites possess neurotoxic properties [148]. (For example, salsolinol and its metabolites have been implicated to be involved in the pathogenesis of Parkinson's disease [152]. It has been reported that salsolinol can induce accelerated apoptotic cell death in the presence of copper in neuroblastoma cells [153]. Evidence indicates that salsolinol can elicit apoptosis, possibly via generation of reactive oxygen species [154]. Interestingly, it is has been noted that salsolinol may either decrease or increase the generation of hydroxyl radicals [148]. Therefore, it has been postulated that salsolinol represents a double-faced molecule that can act either as a neuroprotector or a neurotoxin. Hypothesis holds that the disbalance in the proportion of neuroprotectivity and neurotoxicty of salsolinol leads to diseases such as Parkinson's disease [155].

Melanin is synthesised from L-DOPA via the polymerisation of DOPA chrome [156]. This metabolite is known to protect the skin from solar carcinogenesis [30]. Although, it has also been found that melanin can generate free radicals and also cause oxidative DNA damage [30]. Evidence has indicated that melanin on UV irradiation produces base modification and strand breaks in whole cells $[157,158]$. Melanin has also been shown to bind to several metal ions such as iron, copper and zinc [159]. Studies in our lab have shown that melanin is able to damage DNA in the presence of copper ions mediated by ROS [30].

\section{Conclusion}

The high prevalence of sporadic cancer evidenced in our population cannot be justified on the basis of mutagenic capability and concentrations of the exogenous carcinogens present in our environment [160]. Thus, it is evident that mutations due to DNA damage by endogenous sources must play a significant role in most cases of cancer, in addition to exposure to exogenous carcinogens. In the past two decades, the discovery of considerable DNA damage occurring from endogenous sources [161] has provided the major impetus to the field of carcinogenesis research. Subsequently, research focused on the damage incurred by endogenous agents on DNA and the consequences thereof. Several investigations have documented the impact of endogenous background DNA damage on human cancer $[6,161,162]$.

The picture emerging from this review reveals that the genome is vulnerable to hazardous cellular environment, particularly to the incessant flux of reactive products generated by normal or aberrant metabolism. These metabolites can induce damage to DNA by a variety of mechanisms, as discussed in this review. While such substances 
Citation: Rehmani N, Hadi SM (2015) DNA Reactive Activities of Some Endogenous Metabolites and their Putative Role in the Induction of Cancer. J Cancer Sci Ther 7: 283-291. doi:10.4172/1948-5956.1000364

may not possess the potency of several exogenous carcinogens, it can be presumed that lifelong exposure to endogenous toxicants results in accretion of cell damage that leads to many disorders including cancer [163]. It is conceivable that the cumulative effect of endogenous metabolites may be of physiological significance and could contribute to etiology of genetic diseases. Taken together, these findings imply a major contribution of DNA damage in mutagenesis and carcinogenesis.

We are left to grapple with several questions pertaining to the risk contributed by endogenous agents. Is the effect of DNA adduction arising from endogenous agents, additive, synergistic or antagonistic to that caused by exogenous carcinogens? What are the interactions of endogenous metabolites with xenobiotic agents? Also, what are the key steps in the carcinogenesis process that are triggered by endogenous metabolites? Distinguishing between exogenous and endogenous DNA damage is an intricate matter as some exogenous agents also occur endogenously and generate same DNA adducts as endogenous metabolites. While evaluating the contribution of endogenous metabolites in inducing DNA damage, a point worth being taken into consideration is that some of these substances are produced from more than one source. Unfortunately, due to technical and theoretical restrictions in current understandings of cancer origin, answers to such questions are presently beyond our grasp. These matters need to be addressed before the biological significance of endogenous metabolites may be fully appreciated.

It is expected that developments in analytical methodology will continue to progress at a swift pace, enabling sensitive ways to detect and quantitate endogenous DNA damage. Further, we need to accumulate more information on the biological consequences of DNA damage that arises due to endogenous processes. Such findings are crucial to the development of novel chemopreventive strategies. It is obvious that if an approach could be developed leading to a diminution in endogenous DNA damage, the incidence of cancer may be significantly reduced.

\section{Acknowledgements}

We want to admittedly mention that although we tried to provide a comprehensive overview on the subject, we might have inadvertently missed few good studies and relevant observations related to the field of study.

The authors declare no conflict of interest. The authors alone are responsible for the content and writing of this manuscript.

\section{References}

1. Weinberg RA (1996) How cancer arises. Sci Am 275: 62-70.

2. Fearon ER, Vogelstein B (1990) A genetic model for colorectal tumorigenesis. Cell 61: 759-767.

3. Miller JA (1970) Carcinogenesis by chemicals: an overview--G. H. A. Clowes memorial lecture. Cancer Res 30: 559-576.

4. Miller EC, Miller JA (1981) Searches for ultimate chemical carcinogens and their reactions with cellular macromolecules. Cancer 47: 2327-2345.

5. Pilot HC (1986) Fundamentals of oncology, 3rd ed, Marcel Dekker, NY.

6. De Bont R, van Larebeke N (2004) Endogenous DNA damage in humans: a review of quantitative data. Mutagenesis 19: 169-185.

7. Miller EC, Miller JA (1966) Mechanisms of chemical carcinogenesis: nature of proximate carcinogens and interactions with macromolecules. Pharmacol Rev 18: $805-838$

8. Singer B, Grunberger D (1983) Mutagens and carcinogens-a molecular approach. In Molecular biology of mutagens and carcinogens, Plenum, NY. pp. 347.

9. Hemminki K (1983) Nucleic acid adducts of chemical carcinogens and mutagens. Arch Toxicol 52: 249-285.
10. Lawley PD (1989) Mutagens as carcinogens: development of current concepts Mutat Res 213: 3-25.

11. Marnett LJ, Burcham PC (1993) Endogenous DNA adducts: potential and paradox. Chem Res Toxicol 6: 771-785

12. Chakravarti D, Pelling JC, Cavalieri EL, Rogan EG (1995) Relating aromatic hydrocarbon-induced DNA adducts and $\mathrm{C}-\mathrm{H}$-ras mutations in mouse skin papillomas: the role of apurinic sites. Proc Natl Acad Sci U S A 92: 1042210426.

13. Cavalieri E, Rogan E (1997) PAHs and Related Compounds. In The Handbook of Environmental Chemistry. Springer, Heidelberg, Germany.

14. Valko M, Rhodes CJ, Moncol J, Izakovic M, Mazur M (2006) Free radicals metals and antioxidants in oxidative stress-induced cancer. Chem Biol Interact 160: 1-40.

15. lida T, Furuta A, Kawashima M, Nishida J, Nakabeppu Y, et al. (2001) Accumulation of 8-oxo-2'-deoxyguanosine and increased expression of hMTH1 protein in brain tumors. Neuro Oncol 3: 73-81.

16. Li D, Firozi PF, Zhang W, Shen J, DiGiovanni J, et al. (2002) DNA adducts, genetic polymorphisms, and K-ras mutation in human pancreatic cancer. Mutat Res 513: 37-48.

17. Kryston TB, Georgiev AB, Pissis P, Georgakilas AG (2011) Role of oxidative stress and DNA damage in human carcinogenesis. Mutat Res 711: 193-201.

18. Jackson AL, Loeb LA (2001) The contribution of endogenous sources of DNA damage to the multiple mutations in cancer. Mutat Res 477: 7-21.

19. Burcham PC (1999) Internal hazards: baseline DNA damage by endogenous products of normal metabolism. Mutat Res 443: 11-36.

20. Gupta RC, Reddy MV, Randerath K (1982) 32P-postlabeling analysis of nonradioactive aromatic carcinogen--DNA adducts. Carcinogenesis 3: 1081-1092.

21. Dizdaroglu M, Gajewski E (1990) Selected-ion mass spectrometry: assays of oxidative DNA damage. Methods Enzymol 186: 530-544.

22. Fedtke N, Boucheron JA, Turner MJ Jr, Swenberg JA (1990) Vinyl chlorideinduced DNA adducts. I: Quantitative determination of N2,3-ethenoguanine based on electrophore labeling. Carcinogenesis 11: 1279-1285.

23. Chaudhary AK, Nokubo M, Reddy GR, Yeola SN, Morrow JD, et al. (1994) Detection of endogenous malondialdehyde-deoxyguanosine adducts in human liver. Science 265: 1580-1582.

24. Bartsch H, Barbin A, Marion MJ, Nair J, Guichard Y (1994) Formation, detection, and role in carcinogenesis of ethenobases in DNA. Drug Metab Rev 26: 349-371.

25. Burcham PC, Marnett LJ (1994) Site-specific mutagenesis by a propanodeoxyguanosine adduct carried on an M13 genome. J Biol Chem 269 : 28844-28850.

26. Chaudhury AK, Reddy GR, Blair IA, Marnett LJ (1996) Characterisation of an N6-oxopropenyl-20-deoxy-adenosine adduct in malondialdehyde modified DNA using liquid chromatography/electrospray ionization tandem mass spectrometry. Carcinogenesis 17: 1167-1170.

27. Husain S, Hadi SM (1995) Strand scission in DNA induced by L-DOPA in the presence of $\mathrm{Cu}(\mathrm{II})$. FEBS Lett 364: 75-78.

28. Shamsi FA, Hadi SM (1995) Photoinduction of strand scission in DNA by uric acid and Cu(II) Free Radic Biol Med 19: 189-196.

29. Hadi N, Singh S, Ahmad A, Zaidi R (2001) Strand scission in DNA induced by 5 -hydroxytryptamine (serotonin) in the presence of copper ions. Neurosci Lett 308: 83-86.

30. Husain S, Hadi SM (1998) DNA breakage by L-DOPA and Cu(II): breakage by melanin and bacteriophage inactivation. Mutat Res 397: 161-168.

31. Asad SF, Singh S, Ahmad A, Hadi SM (1999) Bilirubin-Cu(II) complex degrades DNA. Biochim Biophys Acta 1428: 201-208.

32. Bhat R, Hadi SM (1994) DNA breakage by tannic acid and Cu(II): sequence specificity of the reaction and involvement of active oxygen species. Mutat Res 313: 39-48.

33. Bhat R, Hadi SM (1994) DNA breakage by tannic acid and Cu(II): generation of active oxygen species and biological activity of the reaction. Mutat Res 313 : 49-55. 
Citation: Rehmani N, Hadi SM (2015) DNA Reactive Activities of Some Endogenous Metabolites and their Putative Role in the Induction of Cancer. J Cancer Sci Ther 7: 283-291. doi:10.4172/1948-5956.1000364

34. Fazal F, Rahman A, Greensill J, Ainley K, Hadi SM, et al. (1990) Strand scission in DNA by quercetin and $\mathrm{Cu}(\mathrm{II})$ : identification of free radical intermediates and biological consequences of scission. Carcinogenesis 11: 2005-2008.

35. Hille R (2005) Molybdenum-containing hydroxylases. Arch Biochem Biophys 433: $107-116$.

36. Davies KJ, Sevanian A, Muakkassah-Kelly SF, Hochstein P (1986) Uric acidiron ion complexes. A new aspect of the antioxidant functions of uric acid. Biochem J 235: 747-754.

37. Kellogg EW 3rd, Fridovich I (1977) Liposome oxidation and erythrocyte lysis by enzymically generated superoxide and hydrogen peroxide. J Biol Chem 252: 6721-6728.

38. Proctor P (1970) Similar functions of uric acid and ascorbate in man? Nature 228: 868.

39. HOWELL RR, WYNGAARDEN JB (1960) On the mechanism of peroxidation of uric acids by hemoproteins. J Biol Chem 235: 3544-3550.

40. Cutler RG (1976) Nature of aging and life maintenance processes. In Interdiscip Top Gerontol Karger, Basel, Switzerland 9: 83-133.

41. Oberley LW, Oberley TD, Buettner GR (1980) Cell differentiation, aging and cancer: the possible roles of superoxide and superoxide dismutases. Med Hypotheses 6: 249-268.

42. Tolmasoff JM, Ono T, Cutler RG (1980) Superoxide dismutase: correlation with life-span and specific metabolic rate in primate species. Proc Natl Acad Sci U S A 77: 2777-2781

43. Sohal RS, Buchan PB (1981) Relationship between fluorescent age pigment physiological age and physical activity in the housefly, Musca domestica. Mech Ageing Dev 15: 243-249.

44. Harman D (1980) Free radical theory of aging: Origin of life, evolution, and aging. Age 3: 100-102.

45. Leibovitz BE, Siegel BV (1980) Aspects of free radical reactions in biological systems: aging. J Gerontol 35: 45-56.

46. Halliwell B (1981) In Age Pigments. Elsevier, Amsterdam, NY. pp: 1-62.

47. Ames BN, Cathcart R, Schwiers E, Hochstein P (1981) Uric acid provides an antioxidant defense in humans against oxidant- and radical-caused aging and cancer: a hypothesis. Proc Natl Acad Sci U S A 78: 6858-6862.

48. Becker BF (1993) Towards the physiological function of uric acid. Free Radic Biol Med 14: 615-631.

49. Mazzali M, Hughes J, Kim YG, Jefferson JA, Kang DH, et al. (2001) Elevated uric acid increases blood pressure in the rat by a novel crystal-independent mechanism. Hypertension 38: 1101-1106.

50. Shimada M, Dass B, Ejaz AA (2011) Paradigm shift in the role of uric acid in acute kidney injury. Semin Nephrol 31: 453-458.

51. Fang J, Alderman MH (2000) Serum uric acid and cardiovascular mortality the NHANES I epidemiologic follow-up study, 1971-1992. National Health and Nutrition Examination Survey. JAMA 283: 2404-2410.

52. Feig DI, Kang DH, Johnson RJ (2008) Uric acid and cardiovascular risk. N Eng J Med 359: 1811-1821.

53. Høieggen A, Alderman MH, Kjeldsen SE, Julius S, Devereux RB, et al. (2004) The impact of serum uric acid on cardiovascular outcomes in the LIFE study. Kidney Int 65: 1041-1049

54. Stellato D, Morrone LF, Di Giorgio C, Gesualdo L (2012) Uric acid: a starring role in the intricate scenario of metabolic syndrome with cardio-renal damage? Intern Emerg Med 7: 5-8.

55. Nakagawa T, Hu H, Zharikov S, Tuttle KR, Short RA, et al. (2006) A causal role for uric acid in fructose-induced metabolic syndrome. Am J Physiol Renal Physiol 290: F625-631.

56. Tang W, Hong Y, Province MA, Rich SS, Hopkins PN, et al. (2006) Familial clustering for features of the metabolic syndrome: the National Heart, Lung, and Blood Institute (NHLBI) Family Heart Study. Diabetes Care 29: 631-636.

57. Fini MA, Elias A, Johnson RJ, Wright RM (2012) Contribution of uric acid to cancer risk, recurrence, and mortality. Clin Transl Med 1: 16.

58. Hammarsten J, Damber JE, Peeker R, Mellström D, Högstedt B (2010) A higher prediagnostic insulin level is a prospective risk factor for incident prostate cancer. Cancer Epidemiol 34: 574-579.

59. Bjørge T, Lukanova A, Jonsson H, Tretli S, Ulmer H, et al. (2010) Metabolic syndrome and breast cancer in the me-can (metabolic syndrome and cancer) project. Cancer Epidemiol Biomarkers Prev 19: 1737-1745.

60. Rose DP, Haffner SM, Baillargeon J (2007) Adiposity, the metabolic syndrome, and breast cancer in African-American and white American women. Endocr Rev 28: 763-777.

61. Giovannucci E (2007) Metabolic syndrome, hyperinsulinemia, and colon cancer: a review. Am J Clin Nutr 86: s836-842.

62. Siddiqui AA (2011) Metabolic syndrome and its association with colorectal cancer: a review. Am J Med Sci 341: 227-231.

63. Petersson B, Trell E (1983) Raised serum urate concentration as risk factor for premature mortality in middle aged men: relation to death from cancer. $\mathrm{Br} \mathrm{Med}$ $\mathrm{J}$ (Clin Res Ed) 287: 7-9.

64. Petersson B, Trell E, Henningsen NC, Hood B (1984) Risk factors for premature death in middle aged men. Br Med J (Clin Res Ed) 288: 1264-1268.

65. Levine W, Dyer AR, Shekelle RB, Schoenberger JA, Stamler J (1989) Serum uric acid and 11.5-year mortality of middle-aged women: findings of the Chicago Heart Association Detection Project in Industry. J Clin Epidemiol 42: 257-267.

66. Shin HS, Lee HR, Lee DC, Shim JY, Cho KH, et al. (2006) Uric acid as a prognostic factor for survival time: a prospective cohort study of terminally ill cancer patients. J Pain Symptom Manage 31: 493-501.

67. Strasak AM, Lang S, Kneib T, Brant LJ, Klenk J, et al. (2009) Use of penalized splines in extended Cox-type additive hazard regression to flexibly estimate the effect of time-varying serum uric acid on risk of cancer incidence: a prospective, population-based study in 78,850 men. Ann Epidemiol 19: 15-24.

68. Halliwell B, Gutteridge JM (1990) The antioxidants of human extracellular fluids. Arch Biochem Biophys 280: 1-8.

69. Kittridge KJ, Willson RL (1984) Uric acid substantially enhances the free radicalinduced inactivation of alcohol dehydrogenase. FEBS Lett 170: 162-164.

70. Tenhunen R, Marver HS, Schmid R (1968) The enzymatic conversion of heme to bilirubin by microsomal heme oxygenase. Proc Natl Acad Sci U S A 61: 748-755.

71. Asad SF, Singh S, Ahmad A, Khan NU, Hadi SM (2001) Prooxidant and antioxidant activities of bilirubin and its metabolic precursor biliverdin: a structure-activity study. Chem Biol Interact 137: 59-74.

72. Kwak JY, Takeshige K, Cheung BS, Minakami S (1991) Bilirubin inhibits the activation of superoxide-producing NADPH oxidase in a neutrophil cell-free system. Biochim Biophys Acta 1076: 369-373.

73. Di Mascio P, Devasagayam TP, Kaiser S, Sies H (1990) Carotenoids, tocopherols and thiols as biological singlet molecular oxygen quenchers. Biochem Soc Trans 18: 1054-1056.

74. Stocker R, Peterhans E (1989) Synergistic interaction between vitamin E and the bile pigments bilirubin and biliverdin. Biochim Biophys Acta 1002: 238-244.

75. Kaur H, Hughes MN, Green CJ, Naughton P, Foresti R, et al. (2003) Interaction of bilirubin and biliverdin with reactive nitrogen species. FEBS Lett 543: 113119

76. Minetti M, Mallozzi C, Di Stasi AM, Pietraforte D (1998) Bilirubin is an effective antioxidant of peroxynitrite-mediated protein oxidation in human blood plasma. Arch Biochem Biophys 352: 165-174.

77. Kirkby KA, Adin CA (2006) Products of heme oxygenase and their potentia therapeutic applications. Am J Physiol Renal Physiol 290: F563-571.

78. Wardle EN, Williams R (1981) Raised serum biliverdin in hepatic necrosis Biochem Med 26: 8-11.

79. Lafarge-Frayssinet C, Frayssinet C (1990) [Oncogenes and tumor promotion] Bull Cancer 77: 475-478.

80. Purcell SM, Wians FH Jr, Ackerman NB Jr, Davis BM (1987) Hyperbiliverdinemia in the bronze baby syndrome. J Am Acad Dermatol 16: 172-177.

81. Bloomer JR, Berk PD, Howe RB, Berlin NI (1971) Interpretation of plasma bilirubin levels based on studies with radioactive bilirubin. JAMA 218: 216-220.

82. Lamola AA, Eisinger J, Blumberg WE, Patel SC, Flores J (1979) Flurorometric 
Citation: Rehmani N, Hadi SM (2015) DNA Reactive Activities of Some Endogenous Metabolites and their Putative Role in the Induction of Cancer. J Cancer Sci Ther 7: 283-291. doi:10.4172/1948-5956.1000364

study of the partition of bilirubin among blood components: basis for rapid microassays of bilirubin and bilirubin binding capacity in whole blood. Anal Biochem 100: 25-42.

83. McDonagh AF, Lightner DA (1985) 'Like a shrivelled blood orange'--bilirubin, jaundice, and phototherapy. Pediatrics 75: 443-455.

84. Stocker R, Yamamoto Y, McDonagh AF, Glazer AN, Ames BN (1987) Bilirubin is an antioxidant of possible physiological importance. Science 235: 1043-1046.

85. Doré S, Takahashi M, Ferris CD, Zakhary R, Hester LD, et al. (1999) Bilirubin formed by activation of heme oxygenase-2, protects neurons against oxidative stress injury. Proc Natl Acad Sci U S A 96: 2445-2450.

86. Foresti R, Goatly H, Green CJ, Motterlini R (2001) Role of heme oxygenase-1 in hypoxia-reoxygenation: requirement of substrate heme to promote cardioprotection. Am J Physiol Heart Circ Physiol 281: H1976-1984.

87. Hayashi S, Takamiya R, Yamaguchi T, Matsumoto K, Tojo SJ, et al. (1999) Induction of heme oxygenase-1 suppresses venular leukocyte adhesion elicited by oxidative stress: role of bilirubin generated by the enzyme. Circ Res 85: 663-671.

88. Diamond I (1977) In Scientific Approaches to Clinical Neurology. Lea and Febiger, Philadelphia. pp: 1212.

89. Odell GB, Schutta HS (1985) In Cerebral Energy, Metabolism and Metabolic Encephalopathy. Plenum Press, NY. pp: 465-467.

90. Meuwissen JATP, Heirwegh KPM (1982) Aspects of bilirubin transport. In Bilirubin. CRC Press, Boca Raton, FL. Pp: 39-83.

91. Schenker S, Hoyumpa AM, McCandless DW (1986) Bilirubin toxicity to the brain (kernicterus) and other tissues. In Bile Pigments and Jaundice. MarcelDekker, NY. pp: 395-419.

92. Karp WB (1979) Biochemical alterations in neonatal hyperbilirubinemia and bilirubin encephalopathy: a review. Pediatrics 64: 361-368.

93. Roy D, Liehr JG (1999) Estrogen, DNA damage and mutations. Mutat Res 424: $107-115$

94. Markides CS, Roy D, Liehr JG (1998) Concentration dependence of prooxidant and antioxidant properties of catecholestrogens. Arch Biochem Biophys 360 105-112.

95. Lacort M, Leal AM, Liza M, Martín C, Martínez R, et al. (1995) Protective effect of estrogens and catecholestrogens against peroxidative membrane damage in vitro. Lipids 30: 141-146.

96. Taniguchi S, Yanase T, Kobayashi T, Takayanagi R, Haji M, et al. (1994) Catechol estrogens are more potent antioxidants than estrogens for the cu2catalyzed oxidation of low or high-density-lipoprotein - antioxidative effects of steroids on lipoproteins. Endocrine J 41: 605- 611.

97. Ayres S, Tang M, Subbiah MT (1996) Estradiol-17beta as an antioxidant: some distinct features when compared with common fat-soluble antioxidants. J Lab Clin Med 128: 367-375.

98. Barrett JC, Wong A, McLachlan JA (1981) Diethylstilbestrol induces neoplastic transformation without measurable gene mutation at two loci. Science 212: 1402-1404.

99. Li JJ, Li SA (1990) Estrogen carcinogenesis in hamster tissues: a critica review. Endocr Rev 11: 524-531.

100. Li SA, Hou X, Li JJ (1996) Estrogen carcinogenesis: A sequential, epigenotoxic multistage process. In Hormonal Carcinogenesis. Springer, NY. pp. 200-208.

101. Randerath K, Liehr JG, Gladek A, Randerath E (1989) Use of the 32P-postlabelling assay to study transplacental carcinogens and transplacental carcinogenesis. In Perinatal and Multigeneration Carcinogenesis. IARC, International Agency for Research on Cancer, Lyon, France. pp. 189-205

102. Gladek A, Liehr JG (1989) Mechanism of genotoxicity of diethylstilbestrol in vivo. J Biol Chem 264: 16847-16852.

103. Gladek A, Liehr JG (1991) Transplacental genotoxicity of diethylstilbestrol. Carcinogenesis 12: 773-776

104. Hertz R (1985) The estrogen problem-retrospect and prospect. In Estrogens in the Environment: II. Influences on Development . Elsevier, NY, USA. pp. 1-11.

105. Marselos M, Tomatis L (1992) Diethylstilboestrol: I, Pharmacology, Toxicology and carcinogenicity in humans. Eur J Cancer 28A: 1182-1189.
106. Kirkman $\mathrm{H}$ (1959) Estrogen-induced tumors of the kidney in Syrian hamsters. J Natl Cancer Inst Monogr 1: 1-59.

107. Li JJ, Li SA, Klicka JK, Parsons JA, Lam LKT (1983) Relative carcinogenic activity of various synthetic and natural estrogens in the Syrian hamster kidney. Cancer Res 43: 5200-5204.

108. Jaggi W, Lutz WK, Schlatter C (1978) Covalent binding of ethinylestradiol and estrone to rat liver DNA in vivo. Chem Biol Interact 23: 13-18.

109. Bolt HM (1979) Metabolism of estrogens--natural and synthetic. Pharmacol Ther 4: 155-181.

110. Cavalieri E, Frenkel K, Liehr JG, Rogan E, Roy D (2000) Estrogens as Endogenous Genotoxic Agents-DNA Adducts and Mutations. J Natl Cancer Inst Monogr 2000: 75-93.

111. Stack DE, Byun J, Gross ML, Rogan EG, Cavalieri EL (1996) Molecular characteristics of catechol estrogen quinones in reactions with deoxyribonucleosides. Chem Res Toxicol 9: 851-859.

112. Cavalieri EL, Stack DE, Devanesan PD, Todorovic R, Dwivedy I, et al. (1997) Molecular origin of cancer: catechol estrogen-3,4-quinones as endogenous tumor initiators. Proc Natl Acad Sci U S A 94: 10937-10942.

113. Liehr JG, Randerath K, Randerath E (1985) Target organ-specific covalent DNA damage preceding diethylstilbestrol-induced carcinogenesis Carcinogenesis 6: 1067-1069.

114. Liehr JG, Avitts TA, Randerath E, Randerath K (1986) Estrogen-induced endogenous DNA adduction: possible mechanism of hormonal cancer. Proc Natl Acad Sci U S A 83: 5301-5305.

115. Liehr JG, Hall ER, Avitts TA, Randerath E, Randerath K (1987) Localization of estrogen-induced DNA adducts and cytochrome P-450 activity at the site of renal carcinogenesis in the hamster kidney. Cancer Res 47: 2156-2159.

116. Liehr JG, Sirbasku DA, Jurka E, Randerath K, Randerath E (1988) Inhibition of estrogen-induced renal carcinogenesis in male Syrian hamsters by tamoxifen without decrease in DNA adduct levels. Cancer Res 48: 779-783.

117. Liehr JG, Ulubelen AA, Strobel HW (1986) Cytochrome P-450-mediated redox cycling of estrogens. J Biol Chem 261: 16865-16870.

118. Roy D, Liehr JG (1988) Temporary decrease in renal quinone reductase activity induced by chronic administration of estradiol to male Syrian hamsters. Increased superoxide formation by redox cycling of estrogen. J Biol Chem 263: 3646-3651.

119. Roy D, Strobel HW, Liehr JG (1991) Cytochrome b5-mediated redox cycling of estrogen. Arch Biochem Biophys 285: 331-338.

120. Seacat AM, Kuppusamy P, Zweier JL, Yager JD (1997) ESR identification of free radicals formed from the oxidation of catechol estrogens by $\mathrm{Cu} 2+$. Arch Biochem Biophys 347: 45-52.

121. Nutter LM, Wu YY, Ngo EO, Sierra EE, Gutierrez PL, et al. (1994) An o-quinone form of estrogen produces free radicals in human breast cancer cells: correlation with DNA damage. Chem Res Toxicol 7: 23-28.

122. Nutter LM, Ngo EO, Abul-Hajj YJ (1991) Characterization of DNA damage induced by 3,4-estrone-o-quinone in human cells. J Biol Chem 266: 16380 16386

123. Esterbauer H, Striegl G, Puhl H, Rotheneder M (1989) Continuous monitoring of in vitro oxidation of human low density lipoprotein. Free Radic Res Commun 6: $67-75$.

124. Malins DC, Polissar NL, Gunselman SJ (1996) Progression of human breast cancers to the metastatic state is linked to hydroxyl radical-induced DNA damage. Proc Natl Acad Sci U S A 93: 2557-2563.

125. Musarrat J, Arezina-Wilson J, Wani AA (1996) Prognostic and aetiological relevance of 8-hydroxyguanosine in human breast carcinogenesis. Eur $\mathrm{J}$ Cancer 32A: 1209-1214.

126. Boyd NF, McGuire V (1990) Evidence of lipid peroxidation in premenopausa women with mammographic dysplasia. Cancer Lett 50: 31-37.

127. Hadi N, Malik A, Azam S, Khan NU, Iqbal J (2002) Serotonin-Cu(II)-mediated DNA cleavage: mechanism of copper binding by serotonin. Toxicol In Vitro 16: 669-674. 
Citation: Rehmani N, Hadi SM (2015) DNA Reactive Activities of Some Endogenous Metabolites and their Putative Role in the Induction of Cancer. J Cancer Sci Ther 7: 283-291. doi:10.4172/1948-5956.1000364

128. Limson J, Nyokong T, Daya S (1998) The interaction of melatonin and its precursors with aluminium, cadmium, copper, iron, lead, and zinc: an adsorptive voltammetric study. J Pineal Res 24: 15-21.

129. Spencer JP, Jenner A, Aruoma OI, Evans PJ, Kaur H, et al. (1994) Intense oxidative DNA damage promoted by L-dopa and its metabolites. Implications for neurodegenerative disease. FEBS Lett 353: 246-250

130. Weinberger DR, Berman KF, Chase TN (1988) Mesocortical dopaminergic function and human cognition. Ann N Y Acad Sci 537: 330-338.

131. Masson G, Mestre D, Blin O (1993) Dopaminergic modulation of visual sensitivity in man. Fundam Clin Pharmacol 7: 449-463.

132. Nieoullon A (2002) Dopamine and the regulation of cognition and attention. Prog Neurobiol 67: 53-83.

133. Liu J, Li Q, Yu Y, Fang X (2003) Spectroscopic and electrochemical studies of DNA breakage induced by dopamine and copper ion. Anal Sci 19: 1099-1102.

134. Cohen G, Heikkila RE (1974) The generation of hydrogen peroxide, superoxide radical, and hydroxyl radical by 6 -hydroxydopamine, dialuric acid, and related cytotoxic agents. J Biol Chem 249: 2447-2452.

135. Graham DG, Tiffany SM, Bell WR Jr, Gutknecht WF (1978) Autoxidation versus covalent binding of quinones as the mechanism of toxicity of dopamine 6-hydroxydopamine, and related compounds toward C1300 neuroblastoma cells in vitro. Mol Pharmacol 14: 644-653.

136. Nappi AJ, Vass E (1994) The effects of glutathione and ascorbic acid on the oxidations of 6-hydroxydopa and 6-hydroxydopamine. Biochim Biophys Acta 1201: 498-504.

137. Segura-Aguilar J, Paris I, Muñoz P, Ferrari E, Zecca L, et al. (2014) Protective and toxic roles of dopamine in Parkinson's disease. J Neurochem 129: 898-915.

138. Gandhi S, Vaarmann A, Yao Z, Duchen MR, Wood NW, et al. (2012) Dopamine induced neurodegeneration in a PINK1 model of Parkinson's disease. PLoS One 7: e37564.

139. Goldstein DS, Sullivan P, Cooney A, Jinsmaa Y, Sullivan R, et al. (2012) Vesicular uptake blockade generates the toxic dopamine metabolite 3,4-dihydroxyphenylacetaldehyde in PC12 cells: relevance to the pathogenesis of Parkinson's disease. J Neurochem 123: 932-943.

140.Lev N, Barhum Y, Pilosof NS, Ickowicz D, Cohen HY, et al. (2013) DJ-1 protects against dopamine toxicity: implications for Parkinson's disease and aging. J Gerontol A Biol Sci Med Sci 68: 215-225.

141.Snyder RD, Friedman MB (1998) Enhancement of cytotoxicity and clastogenicity of I-DOPA and dopamine by manganese and copper. Mutat Res 405: 1-8.

142. Woodgate A, MacGibbon G, Walton M, Dragunow M (1999) The toxicity of 6-hydroxydopamine on PC12 and P19 cells. Brain Res Mol Brain Res 69: 84-92.

143. Groc L, Levine RA, Foster JA, Normile HJ, Weissmann D, et al. (2000) Evidence of deprenyl-insensitive apoptosis of nigral dopamine neurons during development. Brain Res Dev Brain Res 120: 95-98.

144. Naoi M, Maruyama W, Dostert P, Kohda K, Kaiya T (1996) A novel enzyme enantio-selectively synthesizes $(R)$ salsolinol, a precursor of a dopaminergic neurotoxin, N-methyl(R)salsolinol. Neurosci Lett 212: 183-186.
145. Naoi M, Maruyama W, Akao Y, Yi H (2002) Dopamine-derived endogenous $\mathrm{N}$-methyl-(R)-salsolinol: its role in Parkinson's disease. Neurotoxicol Terato 24: $579-591$.

146. Sandler M, Carter SB, Hunter KR, Stern GM (1973) Tetrahydroisoquinoline alkaloids: in vivo metabolites of L-dopa in man. Nature 241: 439-443.

147. Collins MA, Bigdeli MG (1975) Tetrahydroisoquinolines in vivo. I. Rat brain formation of salsolinol, a condensation product of dopamine and acetaldehyde under certain conditions during ethanol intoxication. Life Sci 16: 585-601.

148. Mravec B (2006) Salsolinol, a derivate of dopamine, is a possible modulator of catecholaminergic transmission: a review of recent developments. Physiol Res 55: 353-364.

149. Misu Y, Goshima Y, Ueda H, Okamura H (1996) Neurobiology of L-DOPAergic systems. Prog Neurobiol 49: 415-454.

150. Misu Y, Yue JL, Goshima Y (1995) L-DOPA systems for blood pressure regulation in the lower brainstem. Neurosci Res 23: 147-158.

151.Tedroff JM (1997) The neuroregulatory properties of L-DOPA. A review of the evidence and potential role in the treatment of Parkinson's disease. Rev Neurosci 8: 195-204.

152. Maruyama W, Sobue G, Matsubara K, Hashizume $Y$, Dostert P, et al (1997) A dopaminergic neurotoxin, 1(R), 2(N)-dimethyl-6,7-dihydroxy-,2,3,4tetrahydroisoquinoline, $\mathrm{N}$-methyl(R) salsolinol, and its oxidation product, ,2(N)dimethyl-6,7-dihydroxyisoquinolinium ion, accumulate in the nigro-striatal system of the human brain. Neurosci Lett 223: 61-64.

153. Kim HJ, Soh Y, Jang JH, Lee JS, Oh YJ, et al. (2001) Differential cell death induced by salsolinol with and without copper: possible role of reactive oxygen species. Mol Pharmacol 60: 440-449.

154. Chun HS, Gibson GE, DeGiorgio LA, Zhang H, Kidd VJ, et al. (2001) Dopaminergic cell death induced by $\operatorname{MPP}(+)$, oxidant and specific neurotoxicants shares the common molecular mechanism. J Neurochem 76 : 1010-1021.

155. Maruyama W, Dostert P, Naoi M (1995) Dopamine-derived 1-methyl-6,7dihydroxyisoquinolines as hydroxyl radical promoters and scavengers in the rat brain: in vivo and in vitro studies. J Neurochem 64: 2635-2643.

156. Nicolaus RA (1968) Chemistry of Natural products. In Melanins. Hermann Paris.

157. Hill HZ (1992) The function of melanin or six blind people examine an elephant Bioessays 14: 49-56.

158. Hill HZ, Hill GJ (1987) Eumelanin causes DNA strand breaks and kills cells. Pigment Cell Res 1: 163-170.

159. Andrzejczyk J, Buszman E (1992) Interaction of Fe3+, Cu2+ and Zn2+ with melanin and melanoproteins from bovine eyes. Acta Biochim Pol 39: 85-88.

160. Epe B (2002) Role of endogenous oxidative DNA damage in carcinogenesis: what can we learn from repair-deficient mice? Biol Chem 383: 467-475.

161. Marnett LJ (2000) Oxyradicals and DNA damage. Carcinogenesis 21: 361-370.

162. Wogan GN, Hecht SS, Felton JS, Conney AH, Loeb LA (2004) Environmental and chemical carcinogenesis. Semin Cancer Biol 14: 473-486.

163. Beckman KB, Ames BN (1998) The free radical theory of aging matures Physiol Rev 78: 547-581. 